\title{
Optimization of Emulsifying Activity of Soy Protein Isolate Using Computer-Aided Techniques
}

\author{
Masayoshi SAITO \\ Japan International Research Center for Agricultural Sciences, 1-1 Ohwashi, Tsukuba city, Ibaraki, 305-8686, Japan
}

Received July 12, 2002; Accepted September 19, 2002

\begin{abstract}
The random-centroid optimization (RCO) method using computer was applied to determine the optimum conditions of the emulsifying activity of soy protein isolate. Levels of factors including the temperature during emulsification, $\mathrm{pH}$ of the protein solution and the concentration of $\mathrm{NaCl}$ were optimized. After the second cycle of measurement of the emulsifying activity in 22 samples, we were able to determine the optimum conditions for practical use, namely, a temperature of $30^{\circ} \mathrm{C}, \mathrm{pH} \mathrm{8.2}$, and concentration of $\mathrm{NaCl}$ of $0.35 \mathrm{~mol} / l$. We concluded that this RCO method is suitable for the optimization of food processing conditions with a minimum number of measurements.
\end{abstract}

Keywords: random-centroid optimization, emulsion, soy protein isolate

Since the processing of traditional foods depends on the empirical knowledge of manufacturers, most of the processing is not scientifically clear at present. There are so many factors in food processing such as $\mathrm{pH}$ and temperature which affect the quality of the products that it is difficult to determine the optimum conditions. From an industrial point of view, the relationship between the conditions of processing and quality of the product, as well as the optimum processing conditions must be determined by simple and convenient methods.

There are several optimization methods that have been developed using a computer (Nakai, 1981). Computer-aided optimization techniques are very common in the field of engineering (Nakai, 1990). Random-centroid optimization (RCO) is one such technique, and a group of researchers from the University of British Columbia have published a computer program (Dou et al., 1993; Nakai et al., 1994). This technique, already applied to the optimization of site-directed mutagenesis (Nakai, 1995a), reaction conditions (Nakamura et al., 2001) and food formulation (Arteaga et al., 1994; Saito et al., 1996), was found appropriate for our objective. The program consists of two steps in each cycle. In a random search step, we get experimental conditions which the program randomly selects. Then we input the results and move to a centroid search step. In this step, the program suggests three more experimental conditions which are useful to narrow the range of factors. After these two steps, the program draws maps which suggest the optimum conditions based on trend lines (Nakai, 1995b; Saito \& Nakai, 1998).

Emulsifying property is one of the most important functional properties of proteins for food materials. Proteins are adsorbed onto the oil-water interface and act as an emulsifier. Several structural factors of the proteins were found to affect the emulsifying property. Hydrophobicity (Kato \& Nakai, 1980; Shimizu et al., 1986a), amphiphilicity (Shimizu et al., 1986b; Saito et al., 1995) and flexibility of the protein (Shimizu et al., 1985) were

E-mail: masaito@jircas.affrc.go.jp considered important factors for emulsification. However, emulsification is a complex phenomenon and it remains to be determined how the optimum property of an emulsifier can be obtained.

Soy protein isolate is widely used as a food material, but its emulsifying activity depends on the preparation; we must therefore determine the optimum conditions for each preparation. The $\mathrm{RCO}$ technique was considered to be powerful for such a case. In the current study, the optimum conditions of temperature, $\mathrm{pH}$ and concentration of $\mathrm{NaCl}$ for the emulsifying activity of soy protein isolate were analyzed using the RCO technique.

\section{Materials and Methods}

Materials New Fujipro (Fuji Oil Co., Ltd., Osaka) was used as soy protein isolate. Soybean oil (first grade) was purchased from Wako Pure Chemical Industries (Osaka).

Optimization of the conditions for emulsification The RCO program was obtained from the University of British Columbia (Vancouver, BC, Canada) through Dr. Shuryo Nakai. Levels of factors including the temperature $\left({ }^{\circ} \mathrm{C}\right)$ during emulsification, $\mathrm{pH}$ of the protein solution and concentration of $\mathrm{NaCl}$ $(\mathrm{mol} / \mathrm{l})$ were optimized.

Measurement of emulsifying activity The emulsifying activity index (EAI) was measured by the turbidimetric procedure of Pearce and Kinsella (1978). Soy protein isolate was dissolved in a $\mathrm{NaCl}$ solution and then the $\mathrm{pH}$ was adjusted with $1 \mathrm{M}$ $\mathrm{HCl}$ or $1 \mathrm{M} \mathrm{NaOH}$. Two milliliters of protein solution $(1 \% \mathrm{w} / \mathrm{v})$ and $0.5 \mathrm{~g}$ of soybean oil were homogenized for $3 \mathrm{~min}$ using Polytron PT-7 (Kinematica, Littau-Lucerne, Switzerland) at its maximum speed. During the emulsification, samples were kept at a set temperature in a water bath. A sample $(0.5 \mathrm{ml})$ of the emulsion was diluted with a $0.1 \%(\mathrm{w} / \mathrm{v})$ SDS solution and its turbidity was measured at $500 \mathrm{~nm}$.

\section{Results and Discussion}

The range of each factor which is listed in Table 1 was com- 
paratively wide to prevent the optimum conditions from being out of the range.

Table 2 shows the summarized data for random-centroid optimization. In the first cycle, after inputting the response (EAI) of the nine sets of conditions (No. 1 to No. 9), the computer program showed three centroid conditions (No. 10 to No. 12). After 12 responses were input, the range set was narrower than that in the first cycle as shown in Table 1 . In the second cycle, 7 more conditions were included (No. 13 to No. 19), and the program showed three more centroid conditions for the second cycle (No. 20 to No. 22).

The maximum value of EAI for the first random search was $39.3 \mathrm{~m}^{2} / \mathrm{g}$ and that of the centroid search was $40.9 \mathrm{~m}^{2} / \mathrm{g}$. After the second random search, the maximum value of $46.9 \mathrm{~m}^{2} / \mathrm{g}$ was recorded, and the same value $\left(46.9 \mathrm{~m}^{2} / \mathrm{g}\right)$ was also recorded for the second centroid search although the conditions were different from those of the random search.

Figure 1 shows the mapping of the optimization of the emulsification formula designed according to the method of Nakai (1990). There are several straight and curved lines on the map. These lines are referred to as trend lines and they suggest the existence of optimum conditions. In this experiment, the map of the $\mathrm{pH}$ showed trend lines with clear directions, and that of $\mathrm{NaCl}$ showed lines with undefined directions. These findings indicated

Table 1. Range of factors for random-centroid optimization to maximize the emulsifying activity of soy protein isolate.

\begin{tabular}{lcc}
\hline \multirow{2}{*}{ Factor } & First cycle & Second cycle \\
\cline { 2 - 3 } & Range & Range \\
\hline Temperature $\left({ }^{\circ} \mathrm{C}\right)$ & $25-40$ & $28-35$ \\
$\mathrm{pH}$ & $3-9$ & $7-9$ \\
$\mathrm{NaCl}(\mathrm{mol} / l)$ & $0-0.5$ & $0.2-0.5$ \\
\hline
\end{tabular}

Table 2. Summary of data for random-centroid optimization.

\begin{tabular}{ccccc}
\hline \multicolumn{2}{c}{$\begin{array}{c}\text { Temperature } \\
\left({ }^{\circ} \mathrm{C}\right)\end{array}$} & $\mathrm{pH}$ & $\mathrm{NaCl}(\mathrm{mol} / \mathrm{l})$ & $\begin{array}{c}\text { Response } \\
(\mathrm{EAI} \mathrm{m} / \mathrm{g})\end{array}$ \\
\hline $\begin{array}{c}\text { First cycle } \\
\text { Random search }\end{array}$ & & & & \\
1 & 22.9 & 8.98 & 0.17 & 38.8 \\
2 & 26.2 & 3.45 & 0.40 & 11.1 \\
3 & 37.3 & 6.44 & 0.46 & 28.6 \\
4 & 30.1 & 5.07 & 0.42 & 15.0 \\
5 & 36.6 & 4.77 & 0.03 & 12.0 \\
6 & 25.2 & 4.07 & 0.06 & 14.5 \\
7 & 29.3 & 6.18 & 0.21 & 21.9 \\
8 & 39.0 & 5.84 & 0.41 & 20.3 \\
9 & 29.0 & 8.47 & 0.43 & 39.3 \\
Centroid search & & & & \\
10 & 32.1 & 7.96 & 0.35 & 40.9 \\
11 & 29.4 & 7.88 & 0.27 & 37.4 \\
12 & 31.9 & 7.03 & 0.37 & 36.3 \\
Second cycle & & & & \\
Random search & & & & \\
13 & 32.0 & 8.80 & 0.29 & 41.6 \\
14 & 33.9 & 8.70 & 0.40 & 41.1 \\
15 & 31.4 & 8.46 & 0.37 & 38.8 \\
16 & 33.7 & 7.17 & 0.31 & 34.4 \\
17 & 31.9 & 7.05 & 0.49 & 38.4 \\
18 & 32.4 & 7.93 & 0.24 & 46.9 \\
19 & 28.9 & 8.77 & 0.24 & 38.3 \\
Centroid search & 32.8 & 8.48 & 0.31 & 34.0 \\
20 & 32.2 & 8.23 & 0.29 & 46.9 \\
21 & 32.8 & 8.20 & 0.33 & 33.1 \\
22 & & & & \\
\hline
\end{tabular}

that the $\mathrm{pH}$ strongly affected the emulsifying activity and that the effect of $\mathrm{NaCl}$ was less appreciable in this search range.

There are several rules on how to read the trend lines. For example, upper lines nearer the best response are more reliable than lower lines (Nakai 1995b). Based on the maps with trend lines, the optimum conditions were estimated to be as follows: temperature $30^{\circ} \mathrm{C}, \mathrm{pH} 8.2$, concentration of $\mathrm{NaCl} 0.35 \mathrm{~mol} / \mathrm{l}$. The value of EAI under these conditions was $48.2 \mathrm{~m}^{2} / \mathrm{g}$. If these conditions are not satisfactory, a third cycle should be undertaken. In this case, we finished the optimization after the second cycle, because we obtained the optimum conditions which were practically satisfactory.

In this study, optimization of three factors was achieved after 22 measurements of emulsifying activity were performed. The method is assumed to be suitable for optimization of three to six factors. Even if the number of factors were to increase to five or six, the number of measurements would be less than 50 (Dou et

$\operatorname{EAI}\left(m^{2} / g\right)$
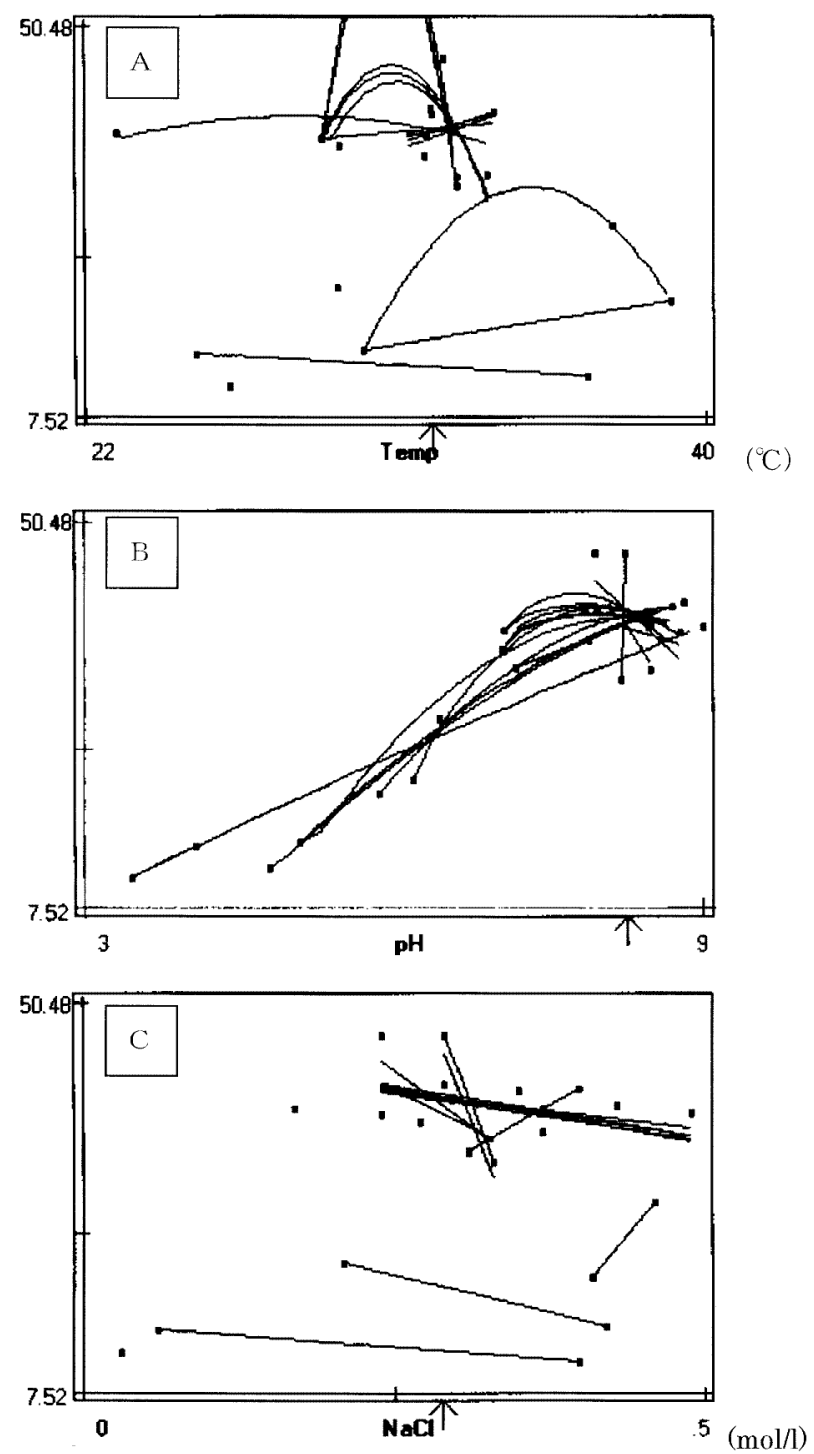

Fig. 1. Mapping of emulsifying activity optimization. A, temperature $\left({ }^{\circ} \mathrm{C}\right)$; $\mathrm{B}, \mathrm{pH} ; \mathrm{C}, \mathrm{NaCl}(\mathrm{mol} / \mathrm{l})$. Maps are drawn according to the method of Nakai (1990). 
al., 1993). This method can be widely applied to optimizing a food formula in many types of food processing.

\section{References}

Arteaga, G.E., Li-Chan, E., Vazquez-Arteaga M.C. and Nakai, S. (1994). Systematic experimental designs for product formula optimization. Trends Food Sci. Tech., 5, 243-254.

Dou, J., Toma, S. and Nakai, S. (1993). Random-centroid optimization for food formulation. Food Res. Int., 26, 27-37.

Kato, A. and Nakai, S. (1980). Hydrophobicity determined by a fluorescence probe method and its correlation with surface properties of proteins. Biochim. Biophys. Acta, 624, 13-20.

Nakai, S. (1981). Comparison of optimization techniques for application to food product and process development. J. Food Sci., 47, 144-152.

Nakai, S. (1990). Computer-aided optimization with potential application in biorheology. J. Jpn. Soc. Biorheol., 4, 143-152.

Nakai, S., Arteaga, G.E. and Li-Chan, E.C.Y. (1994). Computer-aided techniques for quantitative structure activity relationships study of food proteins. In "Protein Functionality in Food Systems," ed. by N.S. Hettiarachchy and G.R. Ziegler. Marcel Dekker Inc., New York, pp. 121-145.

Nakai, S. (1995a). Computer-aided optimization of site-directed mutagenesis of B. stearothermophilus neutral protease. Tezukayama College Food Sci., 17, 49-51.

Nakai, S. (1995b). Random-centroid optimization program for Windows. Tezukayama College Food Sci., 17, 51-55.
Nakamura, K., Hatano, S., Matsuoka, A., Furukawa, N., Takahashi, T. and Yamanaka, Y. (2001). Optimum condition of high pressure treatment for the preparation of lysozyme-dextran complex found by random-centroid optimization. Food Sci. Technol. Res., 7, 84-87.

Pearce, K.N. and Kinsella, J.E. (1978). Emulsifying properties of proteins: evaluation of a turbidimetric method. J. Agric. Food Chem., 26, 716-723.

Saito, M., Ogasawara, M., Chikuni, K. and Shimizu, M. (1995). Synthesis of a peptide emulsifier with an amphiphilic structure. Biosci. Biotechnol. Biochem., 59, 388-392.

Saito, M., Durance, T., Dou, J. and Nakai, S. (1996). Optimization of storage conditions of surimi, IFT Annual Meeting Book of Abstracts, 132.

Saito, M. and Nakai, S. (1998). Application of computer-aided optimization technique for food science. Kagaku to Seibutsu, 36, 12-14 (in Japanese).

Shimizu, M., Saito, M. and Yamauchi, K. (1985). Emulsifying and structural properties of $\beta$-lactoglobulin at different pHs. Agric. Biol. Chem., 49, 189-194.

Shimizu, M., Saito, M. and Yamauchi, K. (1986a). Hydrophobicity and emulsifying activity of milk proteins. Agric. Biol. Chem., 50, 791792.

Shimizu, M., Ametani, A., Kaminogawa, S. and Yamauchi, K. (1986b). The topography of $\alpha_{\mathrm{s} 1}$-casein adsorbed to an oil/water interface: an analytical approach using proteolysis. Biochim. Biophys. Acta, 896, 259-264. 